\title{
Reply to the comments by A D Shukla and P N Shukla
}

\author{
H J Hansen*, D M MohabeY** and P TofT* \\ ${ }^{*}$ Geological Institute, Oster Voldgade 10, DK-1350, Denmark. \\ ** Geological Survey of India, Seminary Hills, Nagpur 440 006, India.
}

The presence of the coccolith Micula prinsii is not indicative of Paleocene deposits but of Uppermost Maastrichtian marine deposits (see e.g., Pospichal 1996), so Shukla and Shukla must be misinformed.

As pointed out by Hansen et al (2001) the marine $\mathrm{K} / \mathrm{T}$ boundary occurs right after the disappearance of Upper Maastrichtian planktonic foraminifera and coccoliths. The marine boundary definition is in this connection of interest only, as far as there is presence of two Ir anomalies at El Kef shortly after the extinction level. The presence of Ir-anomalies has no bearing upon the terrestrial boundary as earlier pointed out by us. We also noted that Ir anomalies have been recorded at other levels than the $\mathrm{K} / \mathrm{T}$ boundary, and that Ir anomalies are not present at all marine $\mathrm{K} / \mathrm{T}$ boundaries. Thus presence of an Ir-anomaly cannot be used as a boundary criterion and definitely not used as the only criterion for the recognition of the boundary.

The fossil evidence (including ostracods, charophytes and fishes) suggests placement of the Anjar lake section in the Maastrichtian (Bajpai and Prasad 2000) while there is no paleontological indication of the presence of a $\mathrm{K} / \mathrm{T}$ boundary, on the contrary - there are Maastrichtian fossils above, between and below the three possible boundary levels!

The radiometric dates referred to by Shukla and Shukla (from Shukla et al 2001) are here presented in figure 1. The Anjar lake sediments are placed between flow 3 and 4 (and are of reversed polarity). The dates place the basaltic series in the later part of the Maastrichtian or in the earlier part of the Paleocene. Since we consider it unlikely that the dinosaurs persisted into Tertiary time, the Anjar sediments with their presence of a partly articulate dinosaur skeleton most likely belong to chron 29R.

Taken at face value, the radiometric ages of the two underlying basalt flows (no. 2 and 3 ) indicate that the flows could well belong to magnetochron $30 \mathrm{~N}$, while the suggested placement of flow 1 in a still earlier normal chron is not supported by the data.

If the Anjar sediments with an exposed thickness of around $2 \mathrm{~m}$ should contain the $\mathrm{K} / \mathrm{T}$ boundary the sediments would represent an accumulation period of around 550,000 years (namely the Cretaceous part of magnetochron 29R). The plot of magnetic susceptibility suggests 3 to 4 minor pulses in the lake sediments, which can be translated into 60 to $80 \mathrm{kyr}$. This also agrees with the intertrappean lake sediments reported by Hansen et al (1996) from Daiwal and Ranipur that both have about the same thickness. It seems unlikely that $2 \mathrm{~m}$ lake sediments should represent a time interval of $550 \mathrm{kyr}$. Other lake sequences (such as part of the North Horn Formation in Utah) are demonstrating accumulation rates of $4-6 \mathrm{~m}$ per $100 \mathrm{kyr}$.

Shukla and Shukla mention sediment thickness of up to $6 \mathrm{~m}$. This is only obtainable if the different sections of the lake sediments are projected onto one imaginary vertical section as already mentioned by Hansen et al (1999). The thickness of the series from five different sections were recorded by Khadkikar et al (1999). No section covers more than $1.8 \mathrm{~m}$. The section of BG 1 was sampled and measured by Mohabey, who noted, that the lower contact to the underlying basalt was not exposed (and it was not exposed at a later visit by Mohabey and Hansen) but Khadkikar et al show that Pit 1

Keywords. Iridium; rhyolites, paleomagnetics; Deccan; Lameta. 


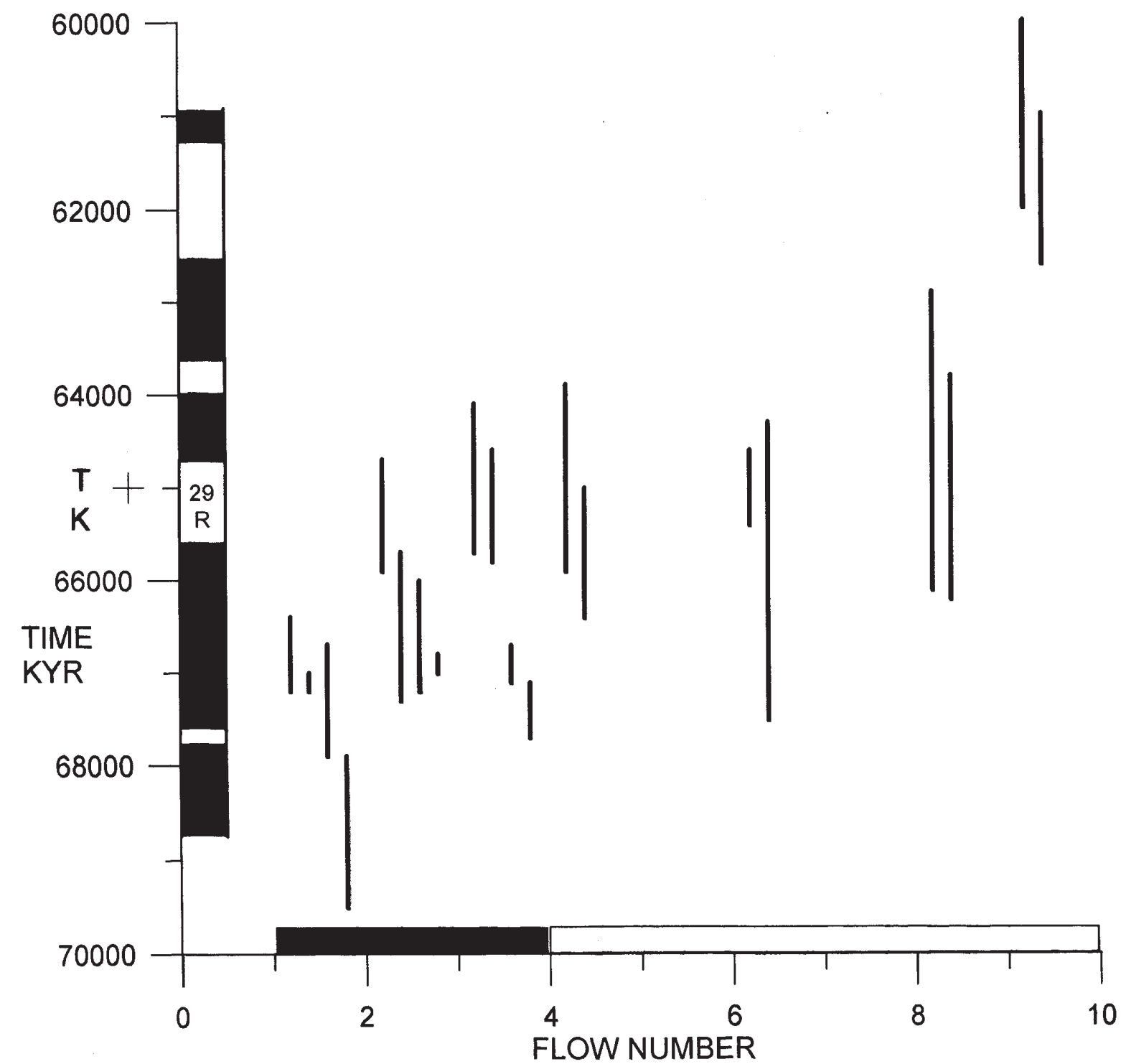

Figure 1. Plot of radiometric dates of basaltic flows from Anjar (data from Shukla et al 2001). Magnetic polarity scale from Cande and Kent (1995). Flows 1-3 are of normal polarity while flows 4-9 are of reversed polarity. The reversed Anjar sediments are found between flows 3 and 4 .

(the BG 1) now exposes $20 \mathrm{~cm}$ of the underlying basalt.

In case the Anjar sediments contained the $\mathrm{K} / \mathrm{T}$ boundary we should, in consequence of the above, expect a hiatus between the Anjar sediments and the underlying basalt flow 3 . There are no reports of a hiatus of this length in the form of e.g., a lateritic bed between flow 3 and 4 .

It would appear, that Shukla and Shukla are attempting to convert the marine boundary into a terrestrial event-boundary where various interesting finds are being linked to a marine stratigraphic boundary, but where a series of unexplained occurrences such as fullerenes, Ni-rich spinels (absent from Anjar), microspherules (absent from Anjar) etc. are being used as safe stratigraphic correlation tools. They are not!
The basic difficulty in establishing the presence of a $\mathrm{K} / \mathrm{T}$ boundary in terrestrial sediments without biostratigraphic control, relates to the lacking precision of radiometric dating and magnetostratigraphy. So far, only two other independent methods are available: Stable carbon isotopes and the magnetic susceptibility pattern.

Shukla and Shukla argue, that magnetic susceptibility of the sediments may be influenced by a wide variety of factors and is of no value for the discussion of presence or absence of a $\mathrm{K} / \mathrm{T}$ boundary in the Anjar Lake. This is a mistake, since the absolute value of magnetic susceptibility of the sediments is of no interest. Some sediments (such as e.g., the Danish white chalk) are even diamagnetic, but in spite of this, the pattern is recognizable from one locality to the next. It is the pattern (which 
we believe to represent orbitally driven climatic changes and thereby precipitation pattern) that forms the basis of our correlations. In our studies of 61 different $\mathrm{K} / \mathrm{T}$ boundaries covering all continents except Australia and Antarctica, we note that the patterns at identical levels constrained by magnetostratigraphy and biostratigraphy allows correlation with high resolution. We are therefore confident, on the basis of our $\mathrm{K} / \mathrm{T}$ boundary sections world-wide, that a characteristic pattern is to be expected at the $\mathrm{K} / \mathrm{T}$ boundary (as reported by Hansen et al 1993, 1996, 2001). This pattern is, however, not found in the Anjar sediments.

The black magnetic microspherules mentioned from the K/T boundary are absent at Anjar. They are only found in marine boundary sections (both at the $\mathrm{K} / \mathrm{T}$ and the $\mathrm{P} / \mathrm{T}$ ) and represent the diagenetic infill of prasinophyte algae (Hansen et al 1986, 2000) and are unrelated to impacts.

The negative shift in organic carbon isotopes at the $\mathrm{K} / \mathrm{T}$ boundary (absent at Anjar) is by our opponents mentioned as caused by world-wide forest fires. Where the shift is present, it is not abrupt, as would be expected from such a scenario. The abrupt shift in carbonate carbon isotopes reported earlier from El Kef is an artifact (Hansen et al 1996). The raised amount of organic carbon ascribed to forest fires was shown to start much earlier than the $\mathrm{K} / \mathrm{T}$ boundary (Hansen et al 1987). The negative isotopic excursion starts at the $\mathrm{K} / \mathrm{T}$ boundary, but does not have an abrupt course.

The presence of $\mathrm{C} 4$ plants at the $\mathrm{K} / \mathrm{T}$ boundary is, at its best, wishful thinking. The Lameta sediments are well established (Brookfield and Sahni 1987; Mohabey et al 1993; Tandon et al 1995 and Mohabey 1996), as deposited in an alluviallimnic environment under semi-arid conditions. The floral evidence (gymnosperms/conifers and angiosperms/dicots and monocots) were reported by Mohabey et al (1993) and the stable carbon and oxygen isotopes of the Lameta sediments along with dinosaur eggs (Sarkar et al 1991) demonstrate that C3 plants flourished under the semiarid conditions and constituted the food for dinosaurs.

The absence in the Anjar lake sequence of a negative organic carbon isotopic anomaly which is present at numerous other marine and terrestrial boundaries is a fact, which can not be explained by a suggestion of presence of organic carbon from plants with a $\mathrm{C} 4$ photosynthesis system and is a flaw by Shukla and Shukla since the C4 system was not "invented" by nature until mid Tertiary time (Bocherens et al 1993). Expressed briefly: Dinosaurs were not grass-eaters!

Much so-called organic carbon, which should correctly be characterized as non-carbonate car- bon, originates from forest fires and can be characterized as soot. Non-carbonate carbon from plants (C3 type) registers the isotopic composition of the ambient atmospheric $\mathrm{CO}_{2}$ and constitutes an independent correlation tool, which, along with the variation pattern in magnetic susceptibility, is a possible correlation tool between marine and terrestrial sequences.

The non-carbonate carbon present in the sediments most often is preserved in the form of charcoal and soot. Both components are graphitic in nature and as such very difficult to alter isotopically. They may be oxidized, but this will lead to their disappearance, which is not the case at Anjar.

In the Chui Hill section the presence of the $\mathrm{K} / \mathrm{T}$ boundary is indicated by the susceptibility pattern in the Upper Limestone member (cycle zero of Hansen et al 1996) along with the development of a negative organic carbon isotopic anomaly. No typical Paleocene fossils occur above the $\mathrm{K} / \mathrm{T}$ boundary, but the same is true of Maastrichtian fossils. The magnetic susceptibility curve from Chui Hill matches well that from the boundary stratotype at El Kef, Tunisia. The possible absence of fullerenes, micro-diamonds, nano-sized iron oxides, Ni-spinels, microspherules and iridium is of no significance for the placement of the $\mathrm{K} / \mathrm{T}$ boundary in this and other sections.

The presence of low quarts paramorphs after high quarts with glass inclusions is the ultimate indicator of rhyolitic volcanic ash. We never indicated that the rhyolitic ash beds (each associated with an underlying Ir-enriched, rusty, discontinuous horizon) in the Anjar sequence should stem from the Anjar basalts.

Rhyolites exist in the region as Maithani et al (1996) reported from Gujarat (Osham Hills, Dhori Nes and other localities in Saurashtra). However, the ash beds do not necessarily originate from India, since rhyolitic ash may travel enormous distances $(2000 \mathrm{~km}$ in the case of the rhyolitic ash bed at the $\mathrm{P} / \mathrm{T}$ boundary in China (Yin et al 1992).

Shukla and Shukla mention a series of intertrappean sections studied for their content of Ir. It should be pointed out that Chui Hill, Bergi Canal and Jirabad sections are infratrappean and belong to the Lameta Beds.

It is difficult to understand why Shukla and Shukla are calling upon a current or wave action in connection with a tidal environment to explain the deposition of the "lenticular cherty limestone horizon" above the uppermost Ir-enriched stripe. Our interpretation differs from that of our opponents as it is not a lenticular body but represents a palustrine carbonate flat deposited in emerging shore-line areas of the lake. There is no evidence of a tidal flat and it is not necessary to call upon turbulence in order to precipitate carbonates. 
It appears wishful thinking to postulate an initial calm period where the shales bearing the Irstripes were deposited which should later change to a turbulent environment. One can not deliberately ignore that the shale in question (original litholog by Tandon et al, Anjar Field-workshop, 1996, organized by PRL), is rich in shell hash and weathered Deccan basalt debris pointing to a somewhat agitated environment during deposition.

The comment that we have carried out the work without sedimentological analysis is wrong. The section at pit BG-1 has been sampled at $\mathrm{cm}$ scale with lithologging for the purpose of our study and we are well accustomed with the litho- and biofacies of the section at Anjar.

It would appear that the interpretations by Shukla and Shukla were made in order to explain the presence of Maastrichtian fossils above the iridium stripes with the intent of demonstrating their reworked nature. No amount of reworking can explain the presence of a semi-articulated skeleton of Titanosaurus indicus between the two lower Irstripes (Mohabey 2001) as well as the bulk concentration of eggshell fragments and ostracodes (Bajpai and Prasad 2000) above the third and topmost Ir-stripe.

Courtillot et al (2000) mentioned in connection with the red stripes that "these levels cannot be regarded as continuous horizons: they are not well defined and locally display some splitting." Since the overlying rhyolitic bentonites are well-defined, there does not seem to have been enough agitation to prevent their deposition. In case the red stripes have been deposited as air-fall layers they should also be expected to form continuous horizons like the bentonites. By contrast, an origin from leaching of the bentonites fits well with the discontinuous nature of the stripes and thereby supports the interpretation by Hansen et al (op. cit).

In their closing remarks our opponents call upon Courtillot et al (2000) as having presented evidence that "amply prove the presence of KTB at Anjar." This involves (according to Courtillot et al) a time period of 1-2 myr to deposit the $2 \mathrm{~m}$ lake sediments!

The title of our contribution definitely does not need any changes!

\section{References}

Bajpai S and Prasad G V R 2000 Cretaceous age for Ir rich Deccan intertrappean deposits: palaeontological evidence from Anjar western India; J. Geol. Soc. London $157257-$ 260

Bocherens H, Friis E M, Mariotti A and Pedersen K R 1993 Carbon isotope abundances in Mesozoic and Cenozoic fossil plants: Palaeoecological implications; Lethaia 26 347-358
Brookfield M E and Sahni A 1987 Palaeoenvironments of the Lameta beds. Late Cretaceous at Jabalpur, Madhya Pradesh, India: Soils and biotas of a semiarid alluvial plain; Cretaceous Res. 8 1-14

Cande S C and Kent D V 1995 Revised calibration of the geomagnetic polarity time scale for the Late Cretaceous and Cenozoic; J. Geophys. Res. 100 6093-6095

Courtillot V, Gallet Y, Rocchia R, Féraud G, Robin E, Hofmann C, Bhandari N and Ghevariya Z G 2000 Cosmic markers, ${ }^{40} \mathrm{Ar} /{ }^{39} \mathrm{Ar}$ dating and paleomagnetism of the KT sections in the Anjar area of the Deccan large igneous province; Earth and Planetary Science Letters. 182 137156

Hansen H J, Gwozdz R, Bromley R G, Rasmussen K L, Vogensen E W and Pedersen K R 1986 CretaceousTertiary boundary spherules from Denmark, New Zealand and Spain; Bull. Geol. Soc. Denmark 35 75-82

Hansen H J, Rasmussen K L, Gwozdz R and Kunzendorf H 1987 Iridium-bearing carbon black at the CretaceousTertiary boundary; Bull. Geol. Soc. Denmark 36 305-314

Hansen H J, Rasmussen K L, Liu Qingsheng, Benjamini C, Walaszczyk I, Gwozdz R and Stage M 1993 Correlation of marine and terrestrial Upper Cretaceous sediments by their magnetic susceptibility; Bull. Geol. Soc. Denmark 40 175-184

Hansen H J, Toft P, Mohabey D and Sarkar A 1996 Lameta age: Dating the main pulse of the Deccan Traps volcanism; Gondwana Geol. Mag. Spec. vol. 2 365-374

Hansen H J, Lojen S, Toft P, Dolenec T, Tong Jinnan, Michaelsen P and Sarkar A 2000 Magnetic susceptibility and organic carbon isotopes of sediments across some marine and terrestrial Permo-Triassic boundaries; In: Permian-Triassic evolution of Tethys and western Circum-Pacific; Developments in paleontology and stratigraphy (eds) H Yin, Dickins, Shi G R and Tong J 18 (Elsevier) 271-289

Hansen H J, Toft P and Mohabey D M 1999 No K/T boundary at Anjar, Gujarat, India. Deccan trap basalts and the K/T boundary. Abstracts p. 9-10. Physical Res. Lab., Ahmedabad, India.

Hansen H J, Mohabey D M and Toft P 2001 No K/T boundary at Anjar, Gujarat, India: Evidence from magnetic susceptibility and carbon isotopes; Proc. Indian Acad. Sci. (Earth Planet Sci.) $\mathbf{1 1 0}$ no. 2, 133-142

Khadkikar A S, Sant D A, Gogte V and Karanth R V 1999 The influence of Deccan volcanism on climate: Insights from lacustrine intertrappean deposits, Anjar, western India; Palaeogeog. Palaeoclimatol. Palaeoecol. 147 141-149

Maithani P B, Goyal N, Manerjee R, Ramachandran S and Rajendra Singh 1996 Rhyolites of Osham Hills, Saurashtra: A geochemical study; Gondwana Geol. Magaz. Sp. vol. 2 213-224

Mohabey D M 1996 Depositional environment of Lameta Formation (Late Cretaceous of Nand-Dongargaon inland basin, Maharashtra: the fossil and lithological evidences; Mem. Geol. Soc. India 37 363-386

Mohabey D M 2001 Indian dinosaur eggs: A review; Geol. Soc. India $\mathbf{5 8}$ 479-508

Mohabey D M, Udhoji S G and Verma K K 1993 Palaeontological and sedimentological observations on the non-marine Lameta Formation (Upper Cretaceous) of Maharashtra, India: Their palaeoecological and palaeoenvironmental significance; Palaeogeog. Palaeoclimatol. Palaeoecol. 105 83-94

Pospichal J J 1996 Calcareous nannoplankton mass extinction at the Cretaceous/Tertiary boundary: An update; Geol. Soc. Amer. Spec. pap. 307 335-360 
Sarkar A, Bhattacharya S K and Mohabey D M 1991 Stable isotope analysis of dinosaur eggshells: Palaeoenvironmental implications; Geology 19 601-605

Shukla A D, Bhandari N, Kusumgar S, Shukla P N, Ghevariya Z G, Gopalan K and Balaram V 2001 Geochemistry and magnetostratigraphy of Deccan flows at Anjar, Kutch. Proc. Indian Acad. Sci. (Earth Planet. Sci.) $\mathbf{1 1 0}$ no. 2 111-132

Tandon S K, Sood A, Andrews J E and Dennis P F 1995 Palaeoenvironment of the dinosaur bearing
Lameta beds (Maastrichtian), Narmada Valley, central India; Palaeogeog. Palaeoclimatol. Palaeoecol. 117 153184

Yin Hongfu, Huang Siji, Zhang Kexing, Hansen H J, Yang Fengqing, Ding Meihua and Bie Xianmei 1992 The effect of volcanism on the Permo-Triassic mass extinction in south China; In: Permo-Triassic events in the eastern Tethys; World and regional geology 2 (eds) Sweet, Yang Zunyi, Dickins and Yin Hongfu (Cambridge Univ. Press), 146-157

$M S$ received 22 April 2002 